\title{
Sickle cell disease: wheeze or asthma?
}

\author{
Robyn T. Cohen ${ }^{1 *}$, Elizabeth S. Klings ${ }^{2}$ and Robert C. Strunk ${ }^{3}$
}

\begin{abstract}
Sickle cell disease $(S C D)$ is the most common life-limiting genetic disease among African Americans, affecting more than 100,000 people in the United States. Respiratory disorders in patients with sickle cell disease have been associated with increased morbidity and mortality. Associations between asthma and pain, acute chest syndrome (ACS), and even death have long been reported. More recently wheezing, even in the absence of an asthma diagnosis, has gained attention as a possible marker of SCD severity. Several challenges exist with regards to making the diagnosis of asthma in patients with SCD, including the high prevalence of wheezing, evidence of airway obstruction on pulmonary function testing, and/or airway hyperresponsiveness among patients with SCD. These features often occur in isolation, in the absence of other clinical criteria necessary for an asthma diagnosis. In this review we will summarize: 1) Our current understanding of the epidemiology of asthma, wheezing, airway obstruction, and airway responsiveness among patients with SCD; 2) The evidence supporting associations with SCD morbidity; 3) Our understanding of the pathophysiology of airway inflammation in SCD; 4) Current approaches to diagnosis and management of asthma in SCD; and 5) Future directions.
\end{abstract}

Keywords: Sickle cell disease, Asthma, Wheezing, Airway obstruction, Airway hyperresponsiveness, Prevalence, Lung function

\section{Background}

Sickle cell disease (SCD) is the most common life-limiting genetic disease among African Americans, affecting more than 100,000 people in the United States [1]. Respiratory disorders in patients with sickle cell disease have been associated with increased morbidity and mortality. Associations between asthma and pain, acute chest syndrome (ACS), and even death have long been reported. More recently wheezing, even in the absence of an asthma diagnosis, has gained attention as a possible marker of SCD severity. In this review we will summarize: 1) Our current understanding of the epidemiology of asthma, wheezing, airway obstruction, and airway responsiveness among patients with sickle cell disease; 2) The evidence supporting associations with SCD morbidity; 3) Our understanding of the pathophysiology of airway inflammation in SCD; 4) Current treatment options; and 5) Future directions.

\footnotetext{
* Correspondence: robyn.cohen@bmc.org

'Division of Pediatric Pulmonary and Allergy, Department of Pediatrics, Boston University School of Medicine, 850 Harrison Avenue, Boston, MA 02118, USA

Full list of author information is available at the end of the article
}

\section{Asthma in SCD: why all the fuss?}

Asthma is the most common chronic disease of childhood, and African Americans are disproportionately affected. Recent US data demonstrate an asthma prevalence of $15 \%$ among African American children versus $8 \%$ among Caucasian children [2]. Thus, we can extrapolate that a substantial percentage of children with SCD are going to have asthma. In the past decade, there have been studies suggesting that 1) asthma occurs at a similar frequency among African Americans with and without SCD [3-5], although two separate studies suggest that asthma may be more common among those with SCD compared to those without; $[6,7] 2)$ those who have SCD and asthma have higher rates of vaso-occlusive morbidity (pain and ACS episodes) compared to those with SCD and no asthma; $[3,5,6,8]$ and 3) asthma is a risk factor for mortality in SCD $[9,10]$.

Several questions exist with regards to these epidemiologic associations. For the question of asthma prevalence in SCD, there has been no population-based study of individuals with SCD compared to a comparable population without any underlying disease. The best available data are from prospective studies of those with SCD who are generally followed at academic tertiary care SCD centers and enrolled irrespective of symptoms. Data gleaned from these cohorts 
are not necessarily representative of the SCD population at large, making it difficult to truly understand the prevalence of asthma in this population. The Cooperative Study of SCD (CSSCD) was a longitudinal prospective cohort study which began enrolling patients regardless of symptoms or disease severity in 1978. Among 291 participants followed from infancy until at least age 5 years (mean length of follow up $=11$ years) the prevalence of asthma was $17 \%$ [5]. In addition to the CSSCD, the Sleep and Asthma Cohort (SAC) Study, began enrolling 253 children 4-19 years of age with sickle cell anemia (SCA, referring to those with $\mathrm{HbSS}$ and $\mathrm{HbS} \beta^{\circ}$ genotypes) in 2004 and followed them prospectively until 2014. The prevalence of asthma in the well-characterized SAC cohort is $28 \%$ [11]. However, the asthma prevalence reported in SAC may not be truly representative of the general population with SCD, as children were enrolled from three tertiary care centers where clinicians may have had a particularly high index of suspicion for asthma [12]. The Pulmonary Hypertension and Hypoxic Response (PUSH) prospective cohort study enrolled 376 children age 3-20 years regardless of symptoms, and reported an asthma prevalence of $24 \%$ [13]. One crosssectional study conducted in Jamaica compared 80 children with SCD to a control group of 80 non SCD children found that $48 \%$ of the SCD group had ever had "a touch of asthma" compared to $22 \%$ of the control group [6].

Second, and perhaps more important, is how asthma is defined in these studies (Table 1). In the CSSCD cohort where associations between asthma and pain, ACS, and mortality were noted, asthma is defined as a personal or parental report of a physician diagnosis of asthma. Other studies that conclude asthma is a risk factor for morbidity use a similar definition, which is fairly standard for epidemiologic studies of asthma [14-16]. The PUSH study defined "asthma" as the presence of a report of "medical history of asthma or wheezing" without review of the medical record, [17] while SAC defined "asthma " as a parent report of a physician diagnosis plus the use of a controller medication, confirmed by review of the medical record [3]. The big question that many of us are trying to answer is "What exactly IS asthma in SCD? How do we know it when we see it?" Part of the challenge for clinicians caring for SCD patients is that many of the common features of asthma - wheezing, airway obstruction, and even airway hyperresponsiveness during a bronchoprovocation challenge - are common in SCD but occur in isolation without other supporting evidence to warrant an asthma diagnosis. We explore these concepts further in the following sections.

\section{Wheezing: common in SCD and independently associated with morbidity}

Wheezing is a common clinical finding among SCD patients. Data from 1722 ACS episodes that occurred in the
CSSCD cohort, demonstrated wheezing in $11 \%$ of patients upon admission to the hospital, and was ultimately present in $26 \%$ during the course of the ACS episode. Wheezing was equally common among children and adults [18]. In a second multicenter study of 538 patients with 671 episodes of ACS, wheezing was detected during $26 \%$ of ACS episodes [19]. In a retrospective cohort study of 262 children with SCD who presented to an urban emergency department over a 4 year period, $19 \%$ had at least one presentation in which wheezing was documented, although fewer than half of those children carried an asthma diagnosis [20]. In an unselected single center cohort of 114 adults, $30 \%$ had at least two recurrent episodes of wheezing leading to shortness of breath, of whom almost half did not have a diagnosis of asthma [21]. Investigating which SCD patients with observed wheezing should have actually been diagnosed with asthma remains an area for future study.

Wheezing, without a co-existing diagnosis of asthma, has been associated with SCD morbidity in both children and adults. Among 159 children with SCA, DeBaun et al. found that a parental report of an episode of wheezing producing shortness of breath was associated with increased risk of a future episode of ACS (IRR 1.7, $p=0.04$ ) during a median 5.2 years of follow-up [22]. In a prospective cohort of 262 patients with SCD (aged 6-68 years) seen in the Emergency Department, documentation of wheezing on physical exam (irrespective of asthma) was associated with more than two times the incidence of future vasoocclusive and ACS episodes during a 4 year follow-up period [20]. In the aforementioned mentioned study of 114 adults with SCD, while physician-diagnosed asthma was not associated with either increased rates of pain or ACS, 2 or more episodes of severe wheezing was associated with approximately a twofold increase of both vasoocclusive and ACS episodes as well as increased risk of early death (HR 4.2, $95 \%$ CI 1.0-17.5, $p<0.05$ ) [21]. Finally, in addition to prior studies showing respiratory symptoms in known asthmatics precede vaso-occlusive crises, [23, 24] recent evidence suggests a temporal relationship between respiratory symptoms including wheezing and SCD morbidity even in the absence of asthma. In a mostly adult SCD cohort (mean age 29 years) of 47 participants in whom asthma was ruled out via a prospective multistep algorithm that included participant report and medical record review, researchers conducted repeated telephone questionnaire interviews to ascertain the presence of cough or wheeze during consecutive 8 week periods over a mean of 9 months of follow-up. $68 \%$ of participants reported at least one episode of cough or wheeze during the follow-up period, usually in the setting of colds; report of cough and/or wheeze symptoms during one 8 week period was associated with a two-fold increased rate of ED visits for pain in the subsequent 8 week period [25]. 
Table 1 Summary of studies reporting prevalence of asthma in SCD patients

\begin{tabular}{|c|c|c|c|c|c|}
\hline Study (year) & Study design & SCD type & Ages & How defined & Prevalence (\%) \\
\hline Boyd et al. (2006) [5] & $\begin{array}{l}\text { CSSCD: } 291 \text { children enrolled } \\
\text { in prospective cohort study }\end{array}$ & $\mathrm{HbSS}$ & $\begin{array}{l}\text { Enrolled }<6 \text { months } \\
\text { and followed through } \\
>5 \text { years }\end{array}$ & Parent report of physician diagnosis of asthma & $17 \%$ \\
\hline Rosen et al. (2014) [11] & $\begin{array}{l}\text { SAC: } 243 \text { children in a } \\
\text { prospective cohort study }\end{array}$ & $\mathrm{HbSS}$ or $\mathrm{HbS} \beta^{0}$ & $4-19$ years & $\begin{array}{l}\text { Physician diagnosis of asthma and use of asthma } \\
\text { medication ever, via parent report and confirmed } \\
\text { with chart review [3] }\end{array}$ & $28 \%$ \\
\hline Knight-Madden et al. (2005) [6] & $\begin{array}{l}\text { Case control study of } 80 \text { children } \\
\text { with SCD from Jamaica with } 80 \\
\text { age, ethnic matched controls }\end{array}$ & HbSS & $5-10$ years & $\begin{array}{l}\text { Parent report using modified ISAAC questionnaire } \\
\text { ("touch of asthma") for "lifetime asthma;" and } \\
\text { wheeze or cough in past } 12 \text { months lasting } 7 \\
\text { days in absence of URI for "current asthma" }\end{array}$ & $\begin{array}{l}48 \% \text { asthma ever, } \\
41 \% \text { current asthma }\end{array}$ \\
\hline Paul et al. (2013) [13] & $\begin{array}{l}\text { PUSH: } 503 \text { children with SCD } \\
\text { in a prospective cohort study }\end{array}$ & All types & $3-20$ years & $\begin{array}{l}\text { Parent answers yes to question "medical } \\
\text { history of asthma or wheezing" [17] }\end{array}$ & $24 \%$ \\
\hline Cohen et al. (2011) [21] & $\begin{array}{l}114 \text { adults with SCD in a } \\
\text { prospective cohort study }\end{array}$ & All types & $18-72$ years & $\begin{array}{l}\text { Positive response to the ATS-DLD question } \\
\text { "Has a doctor ever diagnosed you with asthma" } \\
\text { plus use of a controller medication }\end{array}$ & $30 \%$ \\
\hline
\end{tabular}




\section{Airway obstruction: common in SCD}

Airway obstruction has been reported to be common among children with SCD, and has been demonstrated as early as infancy. Koumbourlis et al. performed infant pulmonary function tests with 20 SCD infants (including 12 with $\mathrm{HbSS}$ and 8 with mixed heterozygous hemoglobinopathies) and found elevated functional residual capacities (FRC), decreased maximum expiratory flows at FRC, and decreased time at maximum expiratory flows relative to the total expiratory time, suggesting hyperinflation and lower airway obstruction [26] Their group then studied 61 children age 5-18 years with $\mathrm{HbSS}$ and reported a $35 \%$ prevalence of lower airway obstruction, [27] though their definition of an obstructive pattern $\left(\mathrm{FEV}_{1} / \mathrm{FVC}<0.85\right.$, scooping of the flow/volume curve, and a "disproportionately low $\mathrm{FEF}_{25-75} \%$ predicted") [28] differs from the current ATS/ERS guidelines [29]. In the prospective, longitudinal PUSH study, 97 participants with HbSS or $\mathrm{HbS} \beta^{\circ}$ age 7-20 years completed spirometry and plethysmography for lung function classification. 18 children (19 \%) met criteria for obstruction, defined as having an $\mathrm{FEV}_{1} / \mathrm{FVC}$ ratio and either an $\mathrm{FEV}_{1}$ or $\mathrm{FEF} 2_{5-75}$ below the lower limit of normal. Forty-four percent of those with obstruction $(N=8)$ had a history of asthma or wheezing [17].

The significance of lower airway obstruction in SCD is not well understood. In a single institution, referred clinic cohort of 102 children with SCD, lower airway obstruction (defined by the standard ATS/ERS definition of an $\mathrm{FEV}_{1} /$ FVC ratio $<95 \%$ CI for age, gender, and height [30]) was associated with twice the prospective rate of pain compared to those with normal lung function (IRR 2.16 (1.084.26); $P=0.027$ ) [31]. A second retrospective chart review study of 127 patients concluded that a history of ACS events was associated with having lower airway obstruction on spirometry, but the definition of obstruction in that study was single cut-off for the $\mathrm{FEV}_{1} / \mathrm{FVC}$ ratio (85\%) rather than using the current ATS/ERS guidelines [32]. Further longitudinal research is needed to investigate associations between appropriately defined lower airway obstruction and SCD morbidity (i.e., do ACS events in childhood impact lung function in adulthoods? Is airway obstruction associated with future risk of SCD morbidity?).

\section{Airway hyperresponsiveness: common in SCD, but does it matter?}

There are several small cross sectional studies that show a high prevalence of airway hyperresponsiveness in SCD (Table 2). In several small pediatric studies with sample sizes ranging from 21-40 children, airway hyperresponsiveness (AHR) to cold air or methacholine was present in 14-77\% of children with SCD [33-36]. In similar small studies of adults, prevalence of AHR ranged from 31-48\%, three to four fold higher than among control subjects in those studies [37, 38]. Given these small sample sizes, the Sleep and Asthma Cohort research group sought to establish the prevalence of AHR to methacholine in their unselected cohort of 243 children with SCA. When the 99th participant in the study (age $=14$ years) was hospitalized for his first ever vaso-occlusive crisis following his methacholine challenge, [39] the SAC group removed methacholine challenge testing from their protocol. Among the 99 participants who had completed that methacholine testing, 55 had a $\mathrm{PC}_{20}<$ $4 \mathrm{mg} / \mathrm{ml}[40]$.

The significance of the increased prevalence of airway reactivity to methacholine among SCD patients is not well understood. In a pulmonary function and biomarker study of 50 children with SCD and 50 non-SCD controls, Chaudry et al. found no difference in the methacholine dose response slope (DRS [defined as the \% drop in $\mathrm{FEV}_{1}$ per increasing dose of methacholine]) between children with SCD versus controls, but did find that the DRS was higher among children with an asthma diagnosis than those without (4.46 vs $0.64, p=0.006$ ) regardless of their SCD status. That said, in multivariable models, DRS was not associated with $\mathrm{FEV}_{1}, \mathrm{FEV}_{1} / \mathrm{FVC}$, fractional exhaled nitric oxide (FeNO) levels, or IgE among the SCD group [41]. Similarly, among the 99 children with SCA in SAC, the DRS was not associated with $\mathrm{FEV}_{1}$, $\mathrm{FEV}_{1} / \mathrm{FVC}$, or FeNO, and was not associated with having an asthma diagnosis, bronchodilator responsiveness, having positive allergy skin tests, or the peripheral eosinophil count. DRS was, however, associated with increased serum IgE and lactate dehydrogenase (LDH) levels, reflective possibly of increased atopy and hemolysis respectively [40]. The association between methacholine DRS with LDH suggests a unique mechanism of AHR in SCD patients that may be more reflective of SCD pathogenesis than atopy.

Data are conflicting regarding whether airway responsiveness is independently associated with SCD morbidity. Chaudry found no differences in the DRS between those with the more severe HbSS and the milder HbSC genotypes [41]. In terms of whether prior history of ACS is associated with current AHR, Ozbek et al. found that the difference in $\mathrm{PC}_{20}$ results between those with and without a history of ACS did not reach significance (0.64 vs. $3.28 \mathrm{mg} / \mathrm{ml}, p=0.06$ ), though this may have been a function of sample size [36]. Sylvester et al. found no between-group differences in \% drop in $\mathrm{FEV}_{1}$ after cold air challenge between those with and without ACS (median drop of $2.8 \%$ in both groups), and that among the 6 children with a positive cold air challenge, none had a prior history of ACS [33]. In contrast, in a small adult cohort of 31 adults with SCD, there was a significant correlation between the number of retrospective ACS events and the methacholine $\mathrm{PC}_{20}$ [38]. 
Table 2 Summary of studies addressing prevalence and clinical correlates of airway hyperresponsiveness in children and adults with SCD

\begin{tabular}{|c|c|c|c|c|}
\hline Study (year) & Study design & Ages & Prevalence of AHR & Clinical Correlates of AHR \\
\hline Leong et al. (1997) [34] & $\begin{array}{l}\text { Cold air challenge in } 32 \\
\text { children with SCD }\end{array}$ & $6-19$ years & $67 \%$ with $10 \%$ drop in $\mathrm{FEV}_{1}$ & $\begin{array}{l}\text { No difference in prevalence of AHR to cold air } \\
\text { between SCD patients with and without asthma; }\end{array}$ \\
\hline Sylvester et al. (2007) [33] & $\begin{array}{l}\text { Cold air challenge in } 42 \\
\text { children with HbSS }\end{array}$ & $6-16$ years & $14 \%$ with $10 \%$ drop in $\mathrm{FEV}_{1}$ & $\begin{array}{l}\text { No association between prior history of ACS } \\
\text { and likelihood of having a positive cold air } \\
\text { challenge test }\end{array}$ \\
\hline Strunk et al. (2008) [35] & $\begin{array}{l}\mathrm{MCT} \text { in } 21 \text { clinically referred } \\
\text { children with SCD and } \\
\text { respiratory symptoms }\end{array}$ & $5-18$ years & $67 \%$ with $P C_{20}<12.5 \mathrm{mg} / \mathrm{ml}$ & Not evaluated \\
\hline Ozbek et al. (2007) [36] & MCT in 31 children & $6-16$ years & $\begin{array}{l}77 \% \text { with } \mathrm{PC}_{20}<16 \mathrm{mg} / \mathrm{ml}, 58 \\
\% \text { with } \mathrm{PC}_{20}<1 \mathrm{mg} / \mathrm{ml}\end{array}$ & $\begin{array}{l}\text { No differences in } \mathrm{PC}_{20} \text { between those with } \\
\text { and without history of } \mathrm{ACS}(p=0.06)\end{array}$ \\
\hline Field et al. (2011) [40] & $\begin{array}{l}\mathrm{MCT} \text { in } 99 \text { children with } \\
\mathrm{HbSS} \text { or } \mathrm{HbS}^{\circ}\end{array}$ & & $55 \%$ with $\mathrm{PC}_{20}<4 \mathrm{mg} / \mathrm{ml}$ & $\begin{array}{l}\text { Methacholine DRS not associated with STR, } \\
\text { BDR, peripheral blood eosinophil count, or } \\
\text { asthma diagnosis; DRS was associated with } \\
\text { serum IgE and LDH }\end{array}$ \\
\hline Chaudry et al. (2014) [41] & $\begin{array}{l}\text { Cohort study } 50 \text { children } \\
\text { with SCD and } 50 \text { non-SCD } \\
\text { controls, } 93 \text { completed MCT }\end{array}$ & 10-18 years & $\begin{array}{l}\text { Prevalence of } \mathrm{PC}_{20} \text { below a specified } \\
\text { threshold not reported; }\end{array}$ & $\begin{array}{l}\text { No difference in DRS between those DRS } \\
\text { higher in children with asthma in both groups; } \\
\text { No differences in DRS between HbSS and HbSC; } \\
\text { DRS not associated with FEV } \text { FEV }_{1} / \mathrm{FVC}_{1} \text {, FeNO, } \\
\text { or IGE among the SCD group; }\end{array}$ \\
\hline Vendramini et al. (2006) [37] & $\begin{array}{l}\text { MCT in } 26 \text { adults with and } \\
28 \text { controls without SCD }\end{array}$ & $18-41$ years & $\begin{array}{l}\mathrm{PC}_{20}<16 \mathrm{mg} / \mathrm{ml} \text { in } 31 \% \text { of } \\
\mathrm{SCD}, 7 \% \text { of controls }\end{array}$ & $\begin{array}{l}\text { Positive methacholine challenge not associated } \\
\text { with having a baseline obstructive pattern } \\
\text { on spirometry }\end{array}$ \\
\hline Sen et al. (2009) [38] & $\mathrm{MCT}$ in 31 adults with SCD & $18-44$ years & $\begin{array}{l}48 \% \text { with } \mathrm{PC}_{20}<16 \mathrm{mg} / \mathrm{ml}, 42 \% \\
\text { with } \mathrm{PC}_{20}<4 \mathrm{mg} / \mathrm{ml}\end{array}$ & $\begin{array}{l}\text { Significant association between the number } \\
\text { of retrospective ACS events and having a } \\
\text { positive methacholine challenge }\end{array}$ \\
\hline
\end{tabular}

Abbreviations: $A C S$ acute chest syndrome, $B D R$ bronchodilator responsiveness, DRS dose response slope, $M C T$ methacholine challenge test, $P C_{20}$ provocative concentration dose associated with a $20 \%$ drop in $\mathrm{FEV} 1 ;$ $S C D$ sickle cell disease, STR skin test reactivity 


\section{Other asthma features and SCD: markers of atopy and family history of asthma: their relationship to asthma and to SCD morbidity}

Given the association between an asthma "diagnosis" and SCD morbidity juxtaposed with the frequency with which children with SCD have wheezing, airway obstruction, and/or airway hyperresponsiveness, investigators have started to investigate whether other factors that have been related to asthma in non-SCD children could help to diagnose asthma in SCD. Studies looking at whether IgE levels can be used to discriminate between those with and without asthma have been inconsistent. While some studies have demonstrated that children and adults with SCD and asthma have higher IgE levels than those without asthma, [21, 42, 43] Strunk et al. found that there was no difference in IgE levels between those with and without a physician diagnosis of asthma among children in the SAC cohort [3]. Having $\geq 2$ positive skin tests to aeroallergens was more common among those with asthma compared to those without asthma in the SAC cohort, but skin test reactivity did not add much to a predictive model for discriminating "asthma" from "no asthma" in this cohort [3]. Ross et al. reported that SCD children with an asthma diagnosis were more likely to have positive ImmunoCAP testing to a 6-item food allergy panel than children without asthma (61 \% vs. $35 \%, p=$ 0.002) [43]. In terms of family history, a parental history of asthma was one of the most important features discriminating children with a physician diagnosis of asthma from children without asthma [3]. Data from 211 children in the CSSCD cohort demonstrated that having a first degree family relative with asthma was a significant risk factor for a personal history of asthma (odds ratio 6.4, $95 \%$ CI 2.8 to $14.1, p<.001$ ). While parental history of asthma was not associated with increased rates of pain or ACS, sibling history of asthma was independently associated with increased risk of VOC, even after adjusting for personal history of an asthma diagnosis (adjusted IRR 1.91, $95 \%$ CI 1.18 to 3.09, $P=0.008$ ) [44].

Atopic features have been associated with SCD morbidity. In a cohort of 80 Jamaican children with SCD, having at least one positive allergy skin prick test was associated with significantly increased odds of having "recurrent" ACS ( $\geq 2$ episodes, OR 4.8, 95 \% C.I. 1.516.1, $p<0.01$ ) [6]. Among 521 children with SCD in the Silent Cerebral Infarct Trial, both an asthma diagnosis and elevated total serum IgE levels were independently associated with increased rates of ACS events [42]. DeBaun et al. found that having 2 or more positive allergy skin tests was an independent risk factor for future ACS events (IRR 1.87, 95 \% CI 1.16-3.00, $p=0.01)[22]$.
What is known about mechanisms of airway disease in SCD? Animal models of SCD have an exaggerated inflammatory response. Nandedkar et al. compared mice expressing normal human (HbA) or normal murine (Wild type or WT) hemoglobin to transgenic SCD mice. Mice were sensitized to ovalbumin to induce lung inflammation, had a two week recovery period, and then received either high ("HiSen") or low ("LoSen") levels of an inhaled ovalbumin challenge daily for 10 days. $10 \%$ of the SCD mice died during the recovery period prior to initiation of the inhalation challenges, compared to no deaths in the control mice groups. SCD LoSen mice had more airway eosinophilia than HbA or WT LoSen mice, and the SCD HiSen mice had higher IgE levels than WT or HbA mice suggesting increased inflammation. Furthermore, during the inhalation challenge period, $10 \%$ of the LoSen and $30 \%$ of the HiSen SCD mice died, compared with $4 \%$ of the $\mathrm{HbA}$ mice and none of the WT mice, suggesting an impact of inflammation on SCD mortality [45]. In a second study, the same group found that chimeric SCD mice had a higher baseline leukocytosis and IL-13 levels compared with chimeric HbA mice. Following induction of experimental asthma by ovalbumin sensitization, chimeric SCD mice had dramatically increased IL-5 expression, greater airway resistance in the large and small airways, and greater airway responsiveness to methacholine compared to HbA mice, further demonstrating a greater baseline inflammatory profile and subsequent exaggerated airway inflammation among SCD mice [46]. In a more recent study, unsensitized SCD mice had increased perivascular inflammation and evidence of an increased Th2 response including increased total lymphocytes, CD8+ T cells, and CD4+ T cells (with increased total Treg cells) and increased levels of IL-5 when compared to control mice. SCD mice also had more robust responses to ovalbumin in terms of BAL leukocytosis and eosinophilia, higher levels of ovalbumin-specific serum IgE levels, and increased expression of IL- 6 and 13 compared to control mice. Interestingly and in contrast to the previously described study, [46] ovalbumin-sensitized SCD mice had less airway hyperresponsiveness to methacholine than did control mice despite the observed enhanced inflammatory response. The authors hypothesize that this finding could indicate that airway obstruction may not be due to methacholine-induced bronchoconstriction (and thus, less responsive to conventional asthma therapies) but due to alternative SCD-specific mechanisms [47].

Not all studies support the notion that there is an increased Th2 response in SCD. Knight-Madden and colleagues compared cytokine profiles in 80 children with SCD in Jamaica and 53 children with SCD in the United Kingdom to cytokine profiles among local healthy controls. Children with SCD in Jamaica were more likely to 
have asthma and more likely to have increased Th2 cytokines (defined as detectable IL-4/undetectable IFN- $\gamma$ ) than local Jamaican age- and ethnically- matched controls while children in the UK with SCD were less likely to have asthma and increased Th2 cytokines than local controls [48]. This discrepancy was attributed to tropical increases in helminth exposure among the Jamaican children, which promotes a Th2 inflammatory response that may have been particularly exaggerated among the children with SCD [48].

Exhaled nitric oxide (eNO) levels have been examined in patients with SCD. In the general population and in cohorts of children with asthma, eNO has been used as a marker of airway inflammation- and has been associated with several features of atopic asthma such as total serum IgE, peripheral blood eosinophilia, and the FEV1/ FVC ratio in children with asthma $[49,50]$. Studies have demonstrated eNO levels in children with SCD to be lower, [51] higher, [52] or the same [41, 53] as eNO levels in healthy controls. Chaudry et al. compared features of airway function in 50 children with SCD to 50 healthy controls. They found that eNO levels were higher in atopic children compared to those without atopy across both the SCD and control groups, but eNO was not correlated with the degree of airway responsiveness to methacholine among the SCD group [41]. Whether or not eNO measurements can be used as a tool to aide in deciding which children with SCD do or do not have asthma has not been thoroughly investigated. Data from methods of measuring airway inflammation, such as measuring the degree of eosinophilia or neutrophilia from induced sputum, are also lacking.

More recently, investigators have emphasized the role of vascular factors on obstructive airway phenotypes in SCD. In a British study of 25 children with HbSS and 25 age- and ethnic- matched controls, the children with SCD had greater pulmonary capillary blood volume and increased respiratory system resistance $\left(\mathrm{R}_{5} \%\right.$ predicted, as measured by impulse oscillometry) compared to controls. Among the children with HbSS only, pulmonary capillary blood volume was positively correlated with $R_{5}$ and the ratio of residual volume/total lung capacity (RV/TLC), and negatively correlated with $\mathrm{FEV}_{1}$ and mean maximal expiratory flow (MMEF ${ }_{25-75}$ ) suggesting that airway obstruction in SCD may be related to increased cardiac output and increased pulmonary blood volume in response to chronic anemia [54]. The same group of investigators obtained high resolution computed tomography (HRCT), echocardiograms, and pulmonary function tests in 35 adults with SCD and found associations between increased cardiac output on echocardiography, increased pulmonary artery/bronchus ratios on HRCT, increased respiratory system resistance, increased RV/TLC, and decreased $\mathrm{FEV}_{1}$ and
$\mathrm{FEF}_{25-75}$ supporting the notion that abnormalities in pulmonary vascular volumes have effects on airway function in patients with SCD which are independent of asthma [55].

\section{How do we put it all together?}

Wheezing is common in SCD, and may or may not be associated with a diagnosis of asthma in this population. Airway obstruction and airway reactivity are also common but are also poor indicators of asthma in SCD. Both wheezing and pulmonary function test evidence of airway abnormalities may be important markers of SCD severity. The most recent version of the NHLBI guidelines on the Evidence-Based Management of Sickle Cell Disease make the following recommendations: 1) assess for signs and symptoms of respiratory problems by history and physical examination; 2) in patients with signs or symptoms of respiratory problems, further assessment (including pulmonary function testing) is recommended; and 3) in otherwise asymptomatic individuals, screening pulmonary function testing is NOT recommended [56]. The recommendation against screening all individuals for abnormal pulmonary function is based on the paucity of evidence that pulmonary function screening offers clinical benefit or is cost-effective. To date, there have been no published studies regarding interventions targeted towards individuals with abnormal lung function.

We recommend the following for all patients with SCD:

1. Careful symptom screening with a high index of suspicion for: history of wheezing, atopy, family history of asthma, and any history of dyspnea or exercise limitation.

2. Any patient positive for the above historical features should be referred for evaluation with a pulmonologist including pulmonary function testing.

3. Consider allergy testing if symptoms suggest that sensitization to environmental exposures could be exacerbating symptoms.

4. Optimization of SCD management in consultation with a hematologist including consideration of hydroxyurea, currently the only FDA-approved therapy for the management of SCD which reduces morbidity and mortality in these patients.

5. In patients for whom a diagnosis of persistent asthma seems appropriate based on history (repeated episodes of wheezing and cough in response to known triggers, clinical response to bronchodilators, and other historical features consistent with asthma including personal and family history of atopy and first degree relative with asthma), treatment with anti-inflammatory controller therapy according to the NHLBI guidelines is recommended $[3,57]$. 


\section{Conclusions and future directions}

Wheezing and airway function abnormalities are common in SCD, but as is true in the general population, "all that wheezes is not asthma." We first need a better understanding of the mechanisms underlying these common clinical features so that we can differentiate asthma from what Knight-Madden and Greenough have termed "Recurrent Wheezing in Sickle Cell Disease (RWIS)" [58]. Once we have a better understanding of the mechanisms underlying airway abnormalities in SCD we can begin to explore the impact of therapeutic interventions on recurrent wheezing, airway obstruction, and/or asthma on short and long term SCD outcomes. This is an important, understudied area that warrants further investigation in an attempt to reduce morbidity and mortality in these patients.

\begin{abstract}
Abbreviations
ACS: Acute chest syndrome; AHR: Airway hyperresponsiveness; ATS/ ERS: American Thoracic Society/European Respiratory Society; CSSCD: Cooperative Study of Sickle Cell Disease; DRS: Methacholine dose response slope; FeNO: Fractional exhaled nitric oxide; FEF $25-75_{\text {: Average }}$ forced expiratory flow during the middle $25-75 \%$ of a forced expiratory

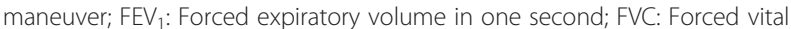
capacity; LDH: Lactate dehydrogenase; $\mathrm{PC}_{20}$ : Provocative concentration dose

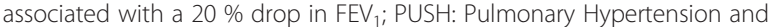
Hypoxic Response study; SAC: Sleep and Asthma Cohort study; SCA: Sickle cell anemia; SCD: Sickle cell disease.
\end{abstract}

\section{Competing interests}

The authors declare that they have no competing interests.

\section{Authors' contributions}

RTC, ESK, and RCS have all been involved in drafting the manuscript, revising it critically for important intellectual content, and have given final approval of the version to be published.

\section{Author details}

${ }^{1}$ Division of Pediatric Pulmonary and Allergy, Department of Pediatrics, Boston University School of Medicine, 850 Harrison Avenue, Boston, MA 02118, USA. ${ }^{2}$ Pulmonary Center, Department of Medicine, Boston University School of Medicine, 72 East Concord Street, Boston, MA 02118, USA. ${ }^{3}$ Division of Allergy, Immunology, and Pulmonary Medicine, Department of Pediatrics, Washington University School of Medicine, 660 South Euclid Avenue, St. Louis, MO, USA.

Received: 29 July 2015 Accepted: 26 November 2015 Published online: 08 December 2015

\section{References}

1. Hassell KL. Population estimates of sickle cell disease in the U.S. Am J Pre Med. 2010;38(4 Suppl):S512-21.

2. Moorman JE, Zahran H, Truman BI, Molla MT, Centers for Disease C, Prevention. Current asthma prevalence - United States, 2006-2008. MMWR Surveill Summ. 2011;60(Suppl):84-6.

3. Strunk RC, Cohen RT, Cooper BP, Rodeghier M, Kirkham FJ, Warner JO, et al. Wheezing symptoms and parental asthma are associated with a physician diagnosis of asthma in children with sickle cell anemia. J Pediatr. 2014; 164(4):821-6. e1.

4. Minniti CP, Sable C, Campbell A, Rana S, Ensing G, Dham N, et al. Elevated tricuspid regurgitant jet velocity in children and adolescents with sickle cell disease: association with hemolysis and hemoglobin oxygen desaturation. Haematologica. 2009:94(3):340-7.

5. Boyd JH, Macklin EA, Strunk RC, DeBaun MR. Asthma is associated with acute chest syndrome and pain in children with sickle cell anemia. Blood. 2006;108(9):2923-7.
6. Knight-Madden JM, Forrester TS, Lewis NA, Greenough A. Asthma in children with sickle cell disease and its association with acute chest syndrome. Thorax. 2005;60(3):206-10.

7. Morris CR. Asthma management: reinventing the wheel in sickle cell disease. Am J Hematol. 2009;84(4):234-41.

8. Nordness ME, Lynn J, Zacharisen MC, Scott PJ, Kelly KJ. Asthma is a risk factor for acute chest syndrome and cerebral vascular accidents in children with sickle cell disease. Clin Mol Allergy. 2005;3(1):2.

9. Knight-Madden JM, Barton-Gooden A, Weaver SR, Reid M, Greenough A. Mortality, asthma, smoking and acute chest syndrome in young adults with sickle cell disease. Lung. 2013;191(1):95-100.

10. Boyd JH, Macklin EA, Strunk RC, DeBaun MR. Asthma is associated with increased mortality in individuals with sickle cell anemia. Haematologica. 2007:92(8):1115-8.

11. Rosen CL, Debaun MR, Strunk RC, Redline S, Seicean S, Craven Dl, et al. Obstructive sleep apnea and sickle cell anemia. Pediatrics. 2014;134(2):273-81.

12. Anim SO, Strunk RC, DeBaun MR. Asthma morbidity and treatment in children with sickle cell disease. Expert Rev Respir Med. 2011;5(5):635-45.

13. Paul R, Minniti CP, Nouraie M, Luchtman-Jones L, Campbell A, Rana S, et al. Clinical correlates of acute pulmonary events in children and adolescents with sickle cell disease. Eur J Haematol. 2013;91(1):62-8.

14. von Mutius E, Schwartz J, Neas LM, Dockery D, Weiss ST. Relation of body mass index to asthma and atopy in children: the National Health and Nutrition Examination Study III. Thorax. 2001;56(11):835-8.

15. Subramanian SV, Kennedy MH. Perception of neighborhood safety and reported childhood lifetime asthma in the United States (U.S.): a study based on a national survey. PloS one. 2009;4(6):e6091.

16. Asher MI, Keil U, Anderson HR, Beasley R, Crane J, Martinez F, et al. International Study of Asthma and Allergies in Childhood (ISAAC): rationale and methods. Eur Respir J. 1995;8(3):483-91.

17. Arteta M, Campbell A, Nouraie M, Rana S, Onyekwere OC, Ensing G, et al. Abnormal pulmonary function and associated risk factors in children and adolescents with sickle cell anemia. J Pediatr Hematol Oncol. 2014;36(3): 185-9.

18. Vichinsky EP, Styles LA, Colangelo LH, Wright EC, Castro O, Nickerson B. Acute chest syndrome in sickle cell disease: clinical presentation and course. Cooperative Study of Sickle Cell Disease. Blood. 1997;89(5):1787-92.

19. Vichinsky EP, Neumayr LD, Earles AN, Williams R, Lennette ET, Dean D, et al. Causes and outcomes of the acute chest syndrome in sickle cell disease. National Acute Chest Syndrome Study Group. N Engl J Med. 2000;342(25): 1855-65.

20. Glassberg JA, Chow A, Wisnivesky J, Hoffman R, Debaun MR, Richardson LD. Wheezing and asthma are independent risk factors for increased sickle cell disease morbidity. Br J Haematol. 2012;159(4):472-9.

21. Cohen RT, Madadi A, Blinder MA, DeBaun MR, Strunk RC, Field JJ. Recurrent, severe wheezing is associated with morbidity and mortality in adults with sickle cell disease. Am J Hematol. 2011;86(9):756-61.

22. DeBaun MR, Rodeghier M, Cohen R, Kirkham FJ, Rosen CL, Roberts I, et al. Factors predicting future ACS episodes in children with sickle cell anemia. Am J Hematol. 2014;89(11):E212-7.

23. Sylvester KP, Patey RA, Broughton S, Rafferty GF, Rees D, Thein SL, et al. Temporal relationship of asthma to acute chest syndrome in sickle cell disease. Pediatr Pulmonol. 2007;42(2):103-6.

24. Glassberg J, Spivey JF, Strunk R, Boslaugh S, DeBaun MR. Painful episodes in children with sickle cell disease and asthma are temporally associated with respiratory symptoms. J Pediatr Hematol Oncol. 2006;28(8):481-5.

25. Diep RT, Busani S, Simon J, Punzalan A, Skloot GS, Glassberg JA. Cough and wheeze events are temporally associated with increased pain in individuals with sickle cell disease without asthma. Br J Haematol. 2015;170(5):732-4.

26. Koumbourlis AC, Hurlet-Jensen A, Bye MR. Lung function in infants with sickle cell disease. Pediatr Pulmonol. 1997;24(4):277-81.

27. Koumbourlis AC, Zar HJ, Hurlet-Jensen A, Goldberg MR. Prevalence and reversibility of lower airway obstruction in children with sickle cell disease. J Pediatr. 2001;138(2):188-92.

28. Lung function testing: selection of reference values and interpretative strategies. American Thoracic Society. Am Rev Respir Dis. 1991;144(5):1202-18. doi:10.1164/ajrccm/144.5.1202

29. Pellegrino R, Viegi G, Brusasco V, Crapo RO, Burgos F, Casaburi R, et al. Interpretative strategies for lung function tests. Eur Respir J. 2005;26(5):948-68.

30. Wang X, Dockery DW, Wypij D, Fay ME, Ferris Jr BG. Pulmonary function between 6 and 18 years of age. Pediatr Pulmonol. 1993;15(2):75-88. 
31. Boyd JH, DeBaun MR, Morgan WJ, Mao J, Strunk RC. Lower airway obstruction is associated with increased morbidity in children with sickle cell disease. Pediatr Pulmonol. 2009;44(3):290-6.

32. Intzes S, Kalpatthi RV, Short R, Imran H. Pulmonary function abnormalities and asthma are prevalent in children with sickle cell disease and are associated with acute chest syndrome. Pediatr Hematol Oncol. 2013;30(8): 726-32.

33. Sylvester KP, Patey RA, Rafferty GF, Rees D, Thein SL, Greenough A. Airway hyperresponsiveness and acute chest syndrome in children with sickle cell anemia. Pediatr Pulmonol. 2007;42(3):272-6.

34. Leong MA, Dampier C, Varlotta L, Allen JL. Airway hyperreactivity in children with sickle cell disease. J Pediatr. 1997;131(2):278-83.

35. Strunk RC, Brown MS, Boyd JH, Bates P, Field JJ, DeBaun MR. Methacholine challenge in children with sickle cell disease: a case series. Pediatr Pulmonol. 2008;43(9):924-9.

36. Ozbek OY, Malbora B, Sen N, Yazici AC, Ozyurek E, Ozbek N. Airway hyperreactivity detected by methacholine challenge in children with sickle cell disease. Pediatr Pulmonol. 2007;42(12):1187-92.

37. Vendramini EC, Vianna EO, De Lucena Al, De Castro FB, Martinez JA, Terra-Filho J. Lung function and airway hyperresponsiveness in adult patients with sickle cell disease. Am J Med Sci. 2006;332(2):68-72.

38. Sen N, Kozanoglu I, Karatasli M, Ermis H, Boga C, Eyuboglu FO. Pulmonary function and airway hyperresponsiveness in adults with sickle cell disease. Lung. 2009;187(3):195-200.

39. Knight-Perry JE, Field JJ, Debaun MR, Stocks J, Kirkby J, Strunk RC. Hospital admission for acute painful episode following methacholine challenge in an adolescent with sickle cell disease. Pediatr Pulmonol. 2009;44(7):728-30.

40. Field JJ, Stocks J, Kirkham FJ, Rosen CL, Dietzen DJ, Semon T, et al. Airway hyperresponsiveness in children with sickle cell anemia. Chest. 2011;139(3): 563-8.

41. Chaudry RA, Rosenthal M, Bush A, Crowley S. Reduced forced expiratory flow but not increased exhaled nitric oxide or airway responsiveness to methacholine characterises paediatric sickle cell airway disease. Thorax. 2014;69:580-5.

42. An P, Barron-Casella EA, Strunk RC, Hamilton RG, Casella JF, DeBaun MR. Elevation of lgE in children with sickle cell disease is associated with doctor diagnosis of asthma and increased morbidity. J Allergy Clin Immunol. 2011; 127(6):1440-6.

43. Ross JG, Bernaudin F, Strunk RC, Kamdem A, Arnaud C, Herve M, et al. Asthma is a distinct comorbid condition in children with sickle cell anemia with elevated total and allergen-specific IgE levels. J Pediatr Hematol Oncol. 2011;33(5):e205-8.

44. Field JJ, Macklin EA, Yan Y, Strunk RC, DeBaun MR. Sibling history of asthma is a risk factor for pain in children with sickle cell anemia. Am J Hematol. 2008;83(11):855-7.

45. Nandedkar SD, Feroah TR, Hutchins W, Weihrauch D, Konduri KS, Wang J, et al. Histopathology of experimentally induced asthma in a murine model of sickle cell disease. Blood. 2008;112(6):2529-38.

46. Pritchard Jr KA, Feroah TR, Nandedkar SD, Holzhauer SL, Hutchins W, Schulte ML, et al. Effects of experimental asthma on inflammation and lung mechanics in sickle cell mice. Am J Respir Cell Mol Biol. 2012;46(3):389-96.

47. Andemariam B, Adami AJ, Singh A, McNamara JT, Secor ER, Guernsey LA, et al. The sickle cell mouse lung: proinflammatory and primed for allergic inflammation. Transl Res. 2015;166(3):254-68.

48. Knight-Madden J, Vergani D, Patey R, Sylvester K, Hussain MJ, Forrester T, et al. Cytokine levels and profiles in children related to sickle cell disease and asthma status. Journal of interferon \& cytokine research : J Interfereon Cytokin Res. 2012;32(1):1-5.

49. Saito J, Inoue K, Sugawara A, Yoshikawa M, Watanabe K, Ishida T, et al. Exhaled nitric oxide as a marker of airway inflammation for an epidemiologic study in schoolchildren. J Allergy Clin Immunol. 2004; 114(3):512-6

50. Strunk RC, Szefler SJ, Phillips BR, Zeiger RS, Chinchilli VM, Larsen G, et al. Relationship of exhaled nitric oxide to clinical and inflammatory markers of persistent asthma in children. J Allergy Clin Immunol. 2003;112(5):883-92.

51. Girgis RE, Qureshi MA, Abrams J, Swerdlow P. Decreased exhaled nitric oxide in sickle cell disease: relationship with chronic lung involvement. Am J Hematol. 2003;72(3):177-84

52. Radhakrishnan DK, Bendiak GN, Mateos-Corral D, Al-Saleh S, Bhattacharjee R, Kirby-Allen $\mathrm{M}$, et al. Lower airway nitric oxide is increased in children with sickle cell disease. J Pediatr. 2011;160(1):93-7.
53. Sullivan K, Kissoon N, Sandler E, Gauger C, Froyen M, Duckworth L, et al. Effect of oral arginine supplementation on exhaled nitric oxide concentration in sickle cell anemia and acute chest syndrome. J Pediatr Hematol Oncol. 2010;32(7):e249-58.

54. Wedderburn CJ, Rees D, Height S, Dick M, Rafferty GF, Lunt A, et al. Airways obstruction and pulmonary capillary blood volume in children with sickle cell disease. Pediatr Pulmonol. 2014;49(7):716-22.

55. Lunt A, Desai SR, Wells AU, Hansell DM, Mushemi S, Melikian N, et al. Pulmonary function, CT and echocardiographic abnormalities in sickle cell disease. Thorax. 2014;69(8):746-51.

56. Yawn BP, Buchanan GR, Afenyi-Annan AN, Ballas SK, Hassell KL, James AH, et al. Management of sickle cell disease: summary of the 2014 evidence-based report by expert panel members. JAMA. 2014;312(10):1033-48.

57. Expert Panel Report 3 (EPR-3). Guidelines for the Diagnosis and Management of Asthma-Summary Report 2007. J Allergy Clin Immunol. 2007;120(5 Suppl):S94-138.

58. Knight-Madden J, Greenough A. Acute pulmonary complications of sickle cell disease. Paediatr Respir Rev. 2014;15(1):13-6.

\section{Submit your next manuscript to BioMed Central and we will help you at every step:}

- We accept pre-submission inquiries

- Our selector tool helps you to find the most relevant journal

- We provide round the clock customer support

- Convenient online submission

- Thorough peer review

- Inclusion in PubMed and all major indexing services

- Maximum visibility for your research

Submit your manuscript at www.biomedcentral.com/submit

C Biomed Central 